\title{
Policies to control red palm weevil based on the recommendations of the Rome meeting
}

\author{
Shoki Al-Dobai \\ IPPC Secretariat, Food and Agriculture Organization of the United Nations, \\ Viale delle Terme di Caracalla, 00153 Rome, Italy, email: Shoki.AlDobai@fao.org
}

\begin{abstract}
Al-Dobai, S. 2019. Policies to control red palm weevil based on the recommendations of the Rome meeting. Arab Journal of Plant Protection, 37(2): 151-152.

The strategies/policies to control red palm weevil (RPW) Rhynchophorus ferrugineus (Olivier) (Coleoptera: Curculionidae) based on the recommendations of the Rome meeting should include the following elements: (i) Regulatory/Phytosanitary system; (ii) Resources; (iii) Programme management; (iv) Stakeholders awareness and involvement; (v) Research and Development; (vi) Monitoring and Evaluation (M\&E). Details related to these elements were presented and discussed.

Keywords: Red palm weevil, quarantine procedures, policies, management strategies, RPW scientific consultation.
\end{abstract}

\section{Introduction}

Red Palm Weevil (RPW) Rhynchophorus ferrugineus (Olivier) (Coleoptera: Curculionidae) is a key pest of palms originating from South and South East Asian Countries that has significantly expanded its geographical and host range during the last three decades. Weak/challenging enforcement of quarantine procedures and difficulties in the early detection of RPW-infested plant materials are considered key factors behind its rapid and constant spread. Although, several control means based on conventional and innovative technologies are available and have been utilized by countries to support their efforts, the results of control are not being satisfactory. The challenge to effectively manage RPW in most of countries can be also attributed to the lack of public awareness, well integrated polices and management strategies that involve all stakeholders, and are supported by adequate human and financial resources.

The framework strategy for eradication of red palm weevil that has been developed and endorsed at the FAOCIHEAM scientific consultation and high-level meeting on red palm weevil management in March 2017, provides clear guidance for the effective policies to be adopted by countries to effectively manage and eradicate RPW.

RPW national strategies/policies should include these six key elements: (i) Regulatory/Phytosanitary system; (ii) Resources; (iii) Programme management; (iv) Stakeholders awareness and involvement; (v) Research and development; (vi) Monitoring and evaluation (M\&E).

\section{Regulatory/Phytosanitary System}

The regulatory/phytosanitary system includes internal and external quarantine, and regulations. There are some common gaps and challenges in the most of national policies behind the failure to control RPW. Illegal/unregulated movement of infested palms within the country and between countries; lack of knowledge on the national phytosanitary legislation on RPW and interference in the imports/movement of planting material by higher ranked officials or other authorities are common challenges. Lack of availability of sources of trustful/certified palms (certified nurseries) within the countries; and poor implementation of phytosanitary (quarantine) measures for transfer of planting materials for new farms or gap filling in existing farm, between regions with in the country contribute to spread pf RPW. In addition; inadequate protocols and certification for export /import of ornamental and exotic palms; and lack of specific regulations/guidelines on phytosanitary measures to regulate the palm trade, especially at the entry points undermine the effective control of RPW.

\section{Resources}

Insufficient human or financial resources to cover laborintensive control and high management cost are one of the obstacles hindering the implementation of national management program. The national polices should make provisions for sufficient qualified and committed human resources and operational financial resource.

\section{Stakeholder's Awareness and Involvement}

Stakeholder's awareness and involvement is crucial element for success the national RPW programme. The national policies should address these three points appropriately: (i) inadequate farmer and other stakeholder involvement in the control program; (ii) insufficient knowledge on the RPW socio-economic and environmental impacts and on the date palm farming systems and farmers organization; (iii) lack of public awareness on the risk associated with RPW in a broad sense.

The national RPW programme should have a clear-cut policy for farmers/stakeholder participation and engagement in RPW-IPM programs. The advantage of involving the farmers in the control program is that they present in the farm 
and can assist in detecting infested palms in early stage of attack that is the key action to control and eradicate the pest. Encouragement of the farmer participation should be supported by stakeholders mapping and needs analysis/studies to set a better knowledge of the socioeconomic consequences of the RPW problem and of the farming systems in the infested areas; and to propose adapted solutions to facilitate the farmers' involvement. Strengthening extension programs and knowledge sharing mechanisms, and improved policies towards incentives to have a positive impact on a better marketing and incomes to farmers could be one of the effective measures.

\section{Program Management}

The national RPW control programs in most of the countries are operated by MoA, while in other countries the responsibility of controlling RPW is implemented by different institutions under the supervision of different ministries with very weak coordination. For efficient functioning and operation of the national RPW control programs the concerned Governments should make provisions to develop a framework for coordination between the national RPW control program and other relevant Governmental and non-Governmental institutions and farmer groups.

Government agencies working with RPW-IPM programs should establish defined linkages and coordination mechanism with cooperatives, NGOs and private sector to make the program more meaningful and effective. Involvement of oasis program in the RPW program in concerned countries is also recommended. Strong engagement and involvement of the law enforcement authorities and other stakeholder organizations is crucial for effective implementation of the phytosanitary measures and limiting the spread and risk of RPW.

\section{Research and Development}

The RPW national program should establish good cooperation with the research institutions and technology developers for sharing the information about the most recent results of research and innovations developed. Testing and validation of recent innovative techniques and methods for detection, surveillance, trapping techniques and management of the RPW that would facilitate the work and improve the effectiveness of the program.

\section{Monitoring and Evaluation}

Currently most of the national RPW-IPM Programs lack the component of the Monitoring and Evaluation (M\&E). This has an adverse impact on the success of the programs, sustaining the positive results achieved and judicious use of resources. National strategies should be based on the Strategic Planning/Results Based Management approaches supported by a logical framework with clear key performance indicators and targets and M\&E mechanism. It is recommended that a midterm and annual evaluation is carried out. It is vital to involve key stakeholders as much as possible in the evaluation process.

\footnotetext{
الملخص

الدبعي، شوقي. 2019. سياساتُ لمكافحة سوسة النخيل الحمراء استناداً لتوصيات اجتماع روما. مجلة وقاية النبات العربية، 37(2): 151-152. إنّ الاسـتر اتيجيات/السـياسـات المثّبعة لمكافحة سـوسـة النخيل الحمر اء Rhynchophorus ferrugineus Olivier (فصـيلة السـوس Curculionidae، رتبة غمديات الأجنحة Coleoptera) وفقاً لتوصيات اجتماع روما يجب أن تشـتمل على العناصـر التالية: 1) نظام رقابة/صـحة نباتية، 2) الموارد، 3) برنامج إدارة، 4)

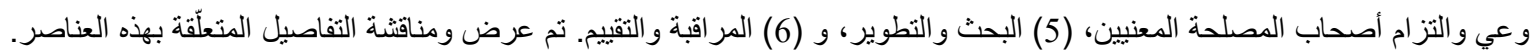
كلمات مفتاحية: سوسة النخيل الحمر اء، تدابير الحجر الزراعي، سياسات، استراتيجيات الإدارة، المشاورة العلمية حول سوسة النخيل الحمراء.
}

\section{References}

Aldobai, S. and M. Ferry. 2017. Proposed multidisciplinary and multi-regional strategy for the management of red palm weevil. Presented at the "Scientific Consultation and High-Level Meeting on Red Palm Weevil Management", organized by FAO and CIHEAM, Italy, 29-31 March, 2017, Rome, Italy.

FAO. 2017. Framework Strategy for Eradication of Red Palm Weevil. http://www.fao.org/3/a-mt054e.pdf (accessed on 30 December, 2018).
FAO. 2017. Current Situation of Red Palm Weevil in the NENA Region [Current situation of management practices, challenges/weaknesses and available research and technologies for its improvement]. http://www.fao.org/3/a-ms664e.pdf (accessed on 30 December, 2018). 